Tim Benton, Manuel Fontán del Junco, María Zozaya (eds.), El gusto moderno. Art Decó en París (1910-1935), Madrid, Fundación Juan March, 2015. 501 pp.

\title{
DECORACIÓN Y LUJO AL ALCANCE DE LA MANO: DE LA EXPOSICIÓN AL CATÁLOGO.
}

\author{
Esther Rodríguez Ortiz* \\ Universidad de Oviedo
}

El gusto moderno. Art déco en París (1910-1935) es el título que da nombre a la exposición que tuvo lugar durante los días 28 de marzo al 26 de junio del 2015 en la Fundación Juan March en Madrid, convirtiéndose en la primera exposición que se organiza en España sobre art déco, y cuyo fruto es el elaborado, amplio y riguroso catálogo que en estas líneas se trata.

En cuanto a la bibliografía existente, tanto a nivel internacional como a nivel nacional, sobre el Art Déco cabe mencionar que la gran mayoría de los títulos que tratan sobre este tema son estudios muy concretos donde se estudian cuestiones tan específicas como las distintas manifestaciones artísticas que se dieron durante ese periodo de tiempo, pero en ningún caso se exponen de manera conjunta y exhaustiva como se hace en este catálogo.

La complejidad que encierra en sí mismo el término art déco, como un estilo o una tendencia que se manifiesta en las artes en las primeras décadas del siglo XX, es una de las cuestiones que se abordan desde el catálogo donde se pretende explicar los condicionantes, influencias y soluciones de esta tendencia, tanto a eruditos como al público en general. Es una exposición donde no sólo las artes decorativas cobran protagonismo sino que también, y a través de los más de trescientos cincuenta objetos de la muestra, la pintura, la escultura y la arquitectura, han quedado representadas. Así, objetos tan dispares entre sí, como pueden ser las revistas, las fotografías, la joyería, el vidrio, el mobiliario, la perfumería, los tejidos, las maquetas o los carteles publicitarios quedan relacionados a través del estilo art déco, formando un todo que hace cobrar sentido al propio término. Un sentido que tiene que ver con esa pretensión moderna de crear algo nuevo, pero también de hacer guiños históricos a través de referencias tomadas de otras fuentes, culturas e influencias.

*E-mail: rodriguezoesther@uniovi.es 
El catálogo, al igual que la exposición, se divide en ocho secciones ordenadas cronológicamente que se corresponden con las temáticas o elementos que se exponen. Tras una introducción desde donde se justifica el motivo de la exposición y se exponen de manera resumida el grueso de las obras, los autores y los elementos complementarios que ayudan a comprender al espectador qué es aquello que se va a encontrar, se hace mención a la fundamental labor de los comisarios, -Tim Benton, Ghislaine Wood, Manuel Fontán del Junco y María Zozaya-, además de las instituciones que han prestado su colaboración. Como decíamos, tras la introducción se pasa a un capítulo titulado "Art déco: estilo y significado", realizado por Tim Benton profesor emérito de Historia del Arte en The Open University, en el que se trata de dar respuestas a las preguntas que se formulan en torno al concepto Art Déco, qué elementos entran dentro de este estilo, si existe algún tipo de motivos que le doten de uniformidad, etc. El autor trata de resolver las incógnitas realizando una introspección histórica del término analizándolo desde el movimiento moderno, centrándose principalmente en Francia y en la figura de Le Corbusier, para pasar a analizarlo fuera de ese país y exponer el caso de Gran Bretaña o Estados Unidos. El capítulo pasa luego a reflexionar sobre el carácter del art déco en cuanto a si es algo propio de las artes decorativas o si también se da en las bellas artes. Nos encontramos con puntos que tratan de despejar esta incógnita a través del arte de vanguardia, la publicidad o la moda, para exponer, como broche, final cuestiones tan importantes como la iconografía del art déco.

José Miguel Marinas, catedrático de filosofía política en la Universidad Complutense de Madrid, en el capítulo "Un mundo que se expone", sostiene que el art déco no surge para adornar la vida sino que su función social o política va mucho más allá, pues debe tenerse en cuenta un dato relevante y es que este característico estilo se mueve entre las dos guerras mundiales, periodo devastador para Europa, y a través del cual se pretende construir una identidad cultural completa y que, a la vez, trata de romper con lo anterior. A través del ornamento, de lo superficial, se construye una apariencia que desmarca al propio objeto, que lo singulariza. En esta nueva cultura de la representación tienen un papel fundamental las exposiciones internacionales como La Exposición Internacional de Artes Decorativas e Industriales Modernas de París en 1925 o la Exposición Universal de Nueva York en 1939.

Emmanuel Bréon, Conservador Jefe de Patrimonio Cité de l'Architecture \& du Patrimoine de París, "El nuevo estilo o el art déco avant la lettre" trata de aclarar el origen del término Art déco a través de ensayos y manifiestos entorno a las artes decorativas y el nacimiento del nuevo estilo. Y para terminar con la sección introductoria, un último capítulo, realizado por Francisco Javier Pérez Rojas, titulado "París 1925: el cocktail está listo para servir", es el broche final, pero también es un elemento introductorio al capítulo que nos ofrece las imágenes de la exposición internacional de las artes decorativas e industriales modernas de París en 1925.

En el catálogo, tras estos trabajos introductorios que explican el origen y singularidades del estilo, se procede a exponer aquellos elementos que dotan de 
cuerpo a la exposición. La moda, el perfume, la joyería y la bisutería, los dibujos de las joyas, así como también los diseños de estampados, los interiores, o el cine, la decoración de los trasatlánticos e incluso la presencia del art déco en España, son sin duda capítulos que amplían los caminos "tradicionales" que se creían propios del estilo que se trata.

Sin duda estamos ante el catálogo de una de las exposiciones más importantes que ha habido en España en los últimos tiempos y para la que han colaborado más de cincuenta instituciones, entre los que se encuentran coleccionistas públicos y privados, no sólo europeos sino también americanos, como el Victorian and Albert Museum de Londres, Cartier, Chanel, Musée d'art et d'historie de Ginebra, la Cité de l'architecture et du patrimoine. Archives d'architecture du XXe siecle de París, el Museo Nacional de Artes Decorativas y el Museo del Traje de Madrid, o el Museu del Disseny de Barcelona. Con todo, este libro pasa a ubicarse en un lugar de suma importancia dentro de la bibliografía que aborda el estudio pormenorizado del Art Déco.

Fecha de recepción: 15 de octubre de 2015

Fecha de revisión: 3 de noviembre de 2015

Fecha de aceptación: 11 de noviembre de 2015 